IRSH 52 (2007), pp. 97-I04 DOI: I0.I0I7/S002085900600280X

(C) 2007 Internationaal Instituut voor Sociale Geschiedenis

\title{
Connecting Migration and World History: Demographic Patterns, Family Systems and Gender
}

\author{
LESLie PAgE MOCH
}

The history of migration is the history of human connections. Migration, then, is a powerful element in world history precisely because it identifies points of contact among peoples and nations and thus provides a deeper understanding of the human experience than institutional or diplomatic perspectives. Here, I seek to connect the global history of migration to family systems, demographic patterns and gender relations - those most intimate connections that bring life to our analyses of the past. A global perspective on historical migrations offers a fascinating challenge to the Europeanist, familiar with the rhythms of European migration and the social and economic systems that gave rise to them. ${ }^{\mathrm{I}}$ In response to Adam McKeown's observations about Asia in world migrations, I focus on Chinese family and gender relations.

To begin, there is a very long history of large-scale migration, both statesponsored and private, within China. Over twenty years ago, James Lee observed that:

Modern scholars generally believe that [...] the Chinese were usually reluctant to leave their ancestral homes; nevertheless there was considerable private migration at all times. The widespread but obsolete view that agrarian life in traditional China was sedentary and static certainly conflicts with the documentary evidence. Ideally, peasants may have preferred to live and die in their native districts, but in reality overpopulation, war, famine, epidemics, natural catastrophes, and government oppression often forced them to seek a living elsewhere. ${ }^{2}$

Kenneth Pomeranz writes that well over Io million Chinese moved to underdeveloped and depopulated areas of China in the seventeenth and eighteenth centuries, and that most established freehold farms and were

I. For Europeanist perspectives, see Klaus Bade, Migration in European History (Cambridge, 2003); and Leslie Page Moch, Moving Europeans: Migration in Western Europe since 1650 (Bloomington, IN, 2003). For recent global migration histories, see Dirk Hoerder, Cultures in Contact: World Migrations in the Second Millennium (Durham, NC, 2002) and Patrick Manning, Migration in World History (London, 2004).

2. James Z. Lee, "Migration and Expansion in Chinese History", in William McNeill and Ruth Adams (eds), Human Migration: Patterns and Policies (Bloomington, IN, I978), p. 26. 
themselves free peasants. ${ }^{3}$ Pomeranz also contrasts free migration within China with less free emigration from Europe, contending that "there was no real European counterpart to the Chinese state's repeated efforts to facilitate mass migration to areas where labor was scarce and to do so on terms that allowed cultivators to remain independent". ${ }^{4}$ While for Europeans, long-distance migration on the continent was discouraged by "a variety of legal barriers, language differences and other obstacles", the migration of Chinese was encouraged. Moreover, he claims, European emigration was not free before I 800 , when, he estimates, migration to the Americas was under I.5 million, and two-thirds of English emigrants were indentured servants.

Years before Pomeranz's conclusions, in 1997, Donna Gabaccia's close reading of the information on Chinese emigration worldwide revealed that indenture was much less common than assumed. "Scarcely more than a third of Chinese migrants were coolies in the narrowest and most pejorative sense of the term (e.g. ensnared to work under conditions bordering on slavery)" - and the Chinese who went to work in South Africa, France, and Great Britain after I 900 "enjoyed conditions of labor and terms of servitude far superior to those in earlier decades". 6

Thus, there was a kind of autonomy to much of Chinese migration; however, like migration everywhere (as well as childbearing and marriage), Chinese migration operated within particular economic, familial, and social frameworks - and the Chinese family system (like family systems everywhere) gave a particular shape to migration. In the article under discussion, Adam McKeown turns to Donna Gabaccia, who "suggests that the differences in migration demographics over the course of the nineteenth century can be understood also by looking at family structure"; that is, just as northern European emigration networks were shaped by a constellation of local and global forces, including "historical contingencies, patterns set by previous migrants, structural economic relations between different parts of the world, and local cultural forces like family structure", so was the case for Chinese as well.7 My primary line of inquiry for this essay is to investigate links between forms of Chinese transnational mobility, demographic patterns and the family.

Throughout the 1840-1940 period (and long before), intense forms of

3. Kenneth Pomeranz, The Great Divergence: Europe, China, and the Making of the Modern World Economy (Princeton, NJ, 2000), p. 84.

4. Ibid.

5. Ibid., pp. $82-83$.

6. Donna R. Gabaccia, "The 'Yellow Peril' and the 'Chinese of Europe': Global Perspectives and Race and Labor, I8I5-I930", in J. Lucassen and L. Lucassen (eds), Migration, Migration History, History: Old Paradigms and New Perspectives (Berne, 1997), pp. 177-196, I 82.

7. Adam McKeown, "Global Migration, I 846-1940", Journal of World History, Is (2004), pp. I55-I89, I 8 I-I 82. 
patriarchy characterized the Chinese family. In his most recent book, Between Sex and Power: Families in the World 1900-2000, Göran Thernborn writes that

Patriarchy was [...] at the very core of Chinese civilization. The father-son relationship was the pivotal social bond, and filial piety, bsiao, the essence of moral obligation. In contrast to the legal Roman concept of [...] fatherly power, bsiao is an ethical concept, denoting a son's duty of unconditional obedience. ${ }^{8}$

Two dynamics flow from this that are powerful in shaping migration patterns and networks. First of all, "patrilineality meant that daughters did not really belong to the family. [...] Female infanticide was frequent, girls could be sold by poor parents to prostitution, or they could be given away as future minor wives to be reared by their future parents-in-law." 9 As Mary Jo Maynes and Ann Waltner emphasize, European parents could not force a daughter into marriage, but law and custom made this possible in China. ${ }^{10}$ Lee and Feng articulate what this meant for Chinese families:

Until recent decades, marriage was arranged by parents and elders; marital life was monitored and controlled by other people. There was little room for personal romance or sexual indulgence. Perhaps most painfully for a society in which the parental relationship is the primary social relationship, many parents were forced to kill or acquiesce in killing their own children. ${ }^{\mathrm{II}}$

As Lee and Feng list the four distinctive aspects of Chinese demographics, they posit that very high mortality is the first - but not only from famine, as Malthusian theorists would have it, but from high female infanticide, which they find perhaps more important in late imperial China. Infanticide has been part of Chinese family life over the centuries. Although Feng and Lee speculate that infanticide declined with opportunities on the frontiers opening in the eighteenth and nineteenth centuries ${ }^{\mathrm{I} 2}$ they also speculate that female infanticide was especially high in the later imperial period, (around the turn of the twentieth century). ${ }^{13}$ Moreover, Ho's analysis of Chinese population studies from the thirteenth century to the I950s shows great evidence for infanticide from skewed sex ratios and local histories of areas in which couples can rear, at most, two

8. Göran Therborn, Between Sex and Power: Family in the World, 1900-2000 (London, 2004), p. 62.

9. Ibid., p. 63. Therborn also writes about foot-binding as an important indicator of patriarchy (ibid., p. I4). This is a fascinating but tangential topic here: see Patricia B. Ebrey, Women and the Family in Chinese History (London, 2003).

ı. Ann B. Waltner and Mary Jo Maynes, "Childhood, Youth and the Female Life Cycle: Women's Life-Cycle Transitions in a World-Historical Perspective: Comparing Marriage in China and Europe", Journal of Women's History, I 2 (200I), pp. I I-20.

II. James Z. Lee and Wang Feng, One Quarter of Humanity: Malthusian Mythology and Chinese Realities, $1700-2000$ (Cambridge, 1999), p. Io.

I2. Ibid., p. I Is.

I3. Ibid., p. 7 . 
sons and a daughter. He describes in detail the way in which parents underwent the drowning of a newborn. ${ }^{14}$ Fei's study of peasant life in the Yangtze valley in the I930s reveals an astonishing paucity of females under the age of five. ${ }^{\text {is }}$ The lack of land meant that the birth of a second son was a problem, despite the strong impulse of filial piety; and less than 40 per cent of the households in the village that he studied included a daughter.

Lee and Feng describe the second characteristic of Chinese demographics as the gender-imbalanced marriage market that came from excess female infant and child mortality. ${ }^{16}$ They and Therborn both note that Chinese women married "universally and early" while men married later or not at all. ${ }^{17}$ In the nineteenth century, when single European women were very thick on the ground and leaving home was an option for many and a necessity for some, almost all Chinese women were married and working in a family system that demanded their labor - usually in their husband's household. ${ }^{18}$ The Chinese female population was trimmed trimmed to meet the needs of a land-poor peasantry, and it just barely met those needs. This left many poor Chinese men without wives and particularly free to emigrate.

These single men were doubtless among the very large male teams that worked in the Peruvian plantations and guano caves, the Trans-Siberian railroad beds, Vladivostok shipyards, and gold mines of the Russian Far East, ${ }^{19}$ as well as on the transcontinental railroad beds and gold mines of California, to say nothing of south-east Asia. It is impossible to know the marital status of all workers, however. In his study of Chinese in Peru, Chicago, and Hawaii from 1900 to 1936, Adam McKeown notes that migration streams to Peru and Chicago were heavily male - indeed, almost exclusively male - in $1900 .{ }^{20}$ Exclusionary legislation did not create male migration streams, he emphasizes; the Chinese did.

It is impossible to know the marital status of Chinese migrant/

I4. Ping-ti Ho, Studies on the Population of China, 1368-1953 (Cambridge, I959; 3rd edn, 1974), pp. 58-59.

I5. Hsiao-Tung Fei, Peasant Life in China: A Field Study of Country Life in the Yangtze Valley (London, 1939), pp. 22, I35.

16. Lee and Feng, One Quarter of Humanity, pp. 7-8. The third distinctive aspect of Chinese demographics is low marital fertility; the fourth, a common resort to fictive kin by adoption, necessitated by low fertility and low survival rates; adoption was widespread despite a "preoccupation with lineage perpetuation" (ibid., p. 8).

17. Ibid., p. 7 and Therborn, Between Sex and Power, p. I39.

I 8. Frans van Poppel, Michel Oris, and James Lee (eds), The Road to Independence: Leaving Home in Western and Eastern Societies, 16th-19th Centuries (Berne, 2004).

19. Adam McKeown, Chinese Networks and Cultural Change: Peru, Chicago, Hawaii, 1900I936 (Chicago, IL, 200I), pp. 44, 53; and Lewis H. Siegelbaum, "Another 'Yellow Peril': Chinese Migrants in the Russian Far East and the Russian Reaction before 1917", Modern Asian Studies, I 2 (1978), pp. 307-330, 312, 314, 316.

20. McKeown, Chinese Networks, p. 58. 
immigrant workers. But some married Chinese men brought their wives along. For example, some peasant families came north to the Russian far east, where their productive agricultural methods outstripped those of the Russian peasants, enabling them to supply cities and railroad workers with vegetables. ${ }^{21}$ And despite anti-Chinese violence, merchants and shopkeepers were part of Vladivostok, Chita, and other Russian far eastern towns, so that by 1908 , an estimated 25 per cent of the people in the Russian far east were Chinese or Korean. ${ }^{22}$

McKeown especially notes that the most female of migration streams he studied were those to Hawaii, where traders and merchants had a long tradition of earning a living, if not thriving. In I 900 about one in seven Chinese in Hawaii ( 13 per cent) was female. It is most striking that these Chinese immigrant wives bore and raised daughters as well as sons in Hawaii. In I896 (two years before Hawaii was annexed to the US and adopted its law excluding Chinese) almost half the Chinese females (46 per cent) were under the age of fifteen, and the great majority had been born in the previous seven years. ${ }^{23}$ Under more prosperous circumstances, then, Chinese female babies survived.

Wives at home in China worked for and with their in-laws - which gave rise to some of the difficult family relations that were the fate of many Chinese wives. Their relations with their own mothers and fathers were generally speaking much less developed than those with their husband's family. The exception was wives in the silk-producing area of the Pearl River delta south of Canton: their earning power gave rise to the custom of "delayed transfer marriage", which enabled them to stay in their original household for an undetermined period of years. ${ }^{24}$

Families were a crucial part of networks for "overland Chinese" whether the emigrant was single or married - family connections were maintained among patriarchs and elder brothers, on one hand, and men sent out to work, on the other. Patriarchy meant that migration and sending money home were not based upon individual decisions, but rather by family directive. This was the case for many other workers of the world as well, but the history of the Chinese family suggests that Chinese workers were especially bound to their families. ${ }^{25} \mathrm{Hsiao}$ Teh-seng, whose correspondence McKeown has mined in Chicago, was enmeshed in a large and powerful family network that included a younger brother in Minneapolis and other relatives in the Midwest, Mexico, and Cuba. The primary correspondent was his elder brother, once in the US, but returned

21. Siegelbaum, "Another 'Yellow Peril'”, p. 3 I4.

22. Ibid., p. 32 I.

23. McKeown, Chinese Networks, p. 4I.

24. Ibid., pp. 72-74.

25. Madeline Hsu, Dreaming of Gold, Dreaming of Home: Transnationalism and Migration between the US and South China, I882-1943 (Stanford, CA, 2000). 
to China. Within weeks of his arrival in the summer of I92I, his brother had asked him to resolve some financial matters for him, including collecting and repaying debts among cousins; many other requests for money and investments followed, including a request to invest in a hosiery factory that would provide remunerative employment for village women at home. Teh-seng's wife and three children also needed money for household expenses and family wedding gifts. Disappointed in Teh-seng, his wife wrote, "I was longing for your money, but all you sent were plain letters". ${ }^{26}$

One implication of such a scenario is that Chinese trans-oceanic migrants were instruments of family decisions to an unusual degree and for this reason, extra caution is advised. That is, family historians such as Alan MacFarlane have suggested ${ }^{27}$ that - as Lee and Feng put it - the European family was the rich soil from which grew individualism and capitalism; the years of independent living before marriage in northwestern Europe (pointed out by John Hajnal) ${ }^{28}$ are understood to be a crucial factor. As a result of this ideological add-on to family history, nonwestern "patriarchy, social formation, and economic processes are all subsumed in a universal binary other that by its very nature is antimodern. China, in particular, is singled out as the personification of this 'other'[...]." "29 Indeed, in the article under discussion, McKeown sees this very kind of attitude behind the supposition that Chinese migrant workers were coolies. My brief foray into the Chinese family suggests that Eurocentric suppositions about the family and modernity are irrelevant and that, worse, they blind scholars to the workings of the family and migration. This certainly has been the case with scholarship about Italian emigrants, where assumptions about patriarchy have prevented a clear view of Italian women until the recent publication of new research on Italian women at home and abroad, edited by Donna Gabaccia and Franca Iacovetta. ${ }^{30}$

Global and comparative work enables historians to note how family forms influence the shape of migration streams; in this essay I am indicating the particular ways that patriarchy and a paucity of women reverberate in world migration patterns. Lines of family authority meant

26. Ibid., pp. $8 \mathrm{I}-83$.

27. Alan Macfarlane, The Origins of English Individualism: The Family, Property and Social Transition (Oxford, 1978).

28. John Hajnal, "The European Marriage Pattern”, in Richard Wall (ed.), Family Forms in Historic Europe (Cambridge, 1983).

29. Lee and Feng, One Quarter of Humanity, p. 5. According to McKeown, anthropologist Fei Hsiao-Tung, cited above for his 1939 case study, had adopted a similar binary view of the Chinese and Westerners by the time of his 1943 book Earthbound China; McKeown, Chinese Networks, pp. 272-274.

30. Donna R. Gabaccia and Franca Iacovetta (eds), Women, Gender and Transnational Lives: Italian Workers of the World (Toronto, 2002). 
that female infants disproportionately did not survive and female children did not thrive; once married, most women spent their lives in their in-laws' household. The high sex ratios of Chinese populations meant that there were very few single women and that many poor men could not find wives; consequently, few women were available to emigrate, particularly in contrast to single men. It is clear from histories of the Chinese family that Chinese desired children and desired to stay in place, but they were often not in a position to do so.

Chinese migration must be seen in the context of longstanding patterns of forced and free movement within China and the powerful state/s that not only decreed movements, but also legally supported the extraordinarily strong patriarchy that enabled Chinese parents to decide which children survived, moved and married. Writ large, these decisions shaped Chinese mobility, with its specific gender and demographic traits. Comparative studies are especially appropriate to illuminate the Chinese family and its relationship to migration patterns worldwide.

Indeed, there are three interlocking comparative family and demographic history projects debating and elucidating the differences among families of the world, including the Chinese family. The first is the "Life at the Extremes" series comparing populations at the opposite ends of Eurasia (Taiwan and the Netherlands); the volumes on the Hajnal hypothesis and on fertility appeared in 2006 and volumes on marriage and mortality will follow. ${ }^{31}$ The second is the Eurasia project, with the primary researchers working on China, Japan, Sweden, Italy, and Belgium. This project was initiated in I994 with a discussion of Akira Hayami's Japanese village registers and after a great deal of international scholarly cooperation, the Eurasia project produced Life under Pressure in 2004. The Eurasia project is about to publish another volume in the MIT University Press series, Eurasian Population and Family History, on fertility, and then perhaps on marriage. There may one day be a volume on migration. ${ }^{32}$ In the meanwhile, another book appeared in 2004 from an overlapping group of European and Asian collaborators called The Road to Independence. ${ }^{33} \mathrm{~A}$ related debate about the Chinese standard of living between scholars I have mentioned, Ken Pomeranz and James Lee, on one hand, and Philip C.C. Huang and others, on the other hand, was published

31. Theo Engelen and Arthur P. Wolf (eds), Marriage and the Family in Eurasia: Perspectives on the Hajnal Hypothesis (Amsterdam, 2006); Ying-chang Chuang, T. Engelen, and A.P. Wolf (eds), Positive or Preventive. Fertility Developments in Taiwan and the Netherlands, I850-1950 (Amsterdam, 2006).

32. Tommy Bengtsson et al. (eds), Life Under Pressure: Mortality and Living Standards in Europe and Asia, 1700-1900 (Cambridge, 2004). I am grateful to George Alter for this information.

33. Van Poppel, Oris, and Lee, The Road to Independence. Unfortunately, there is not an article on China in this volume. 
in 2002 in the Journal of Asian Studies. ${ }^{34}$ Third, a series of conferences and conference volumes is being produced under the leadership of Antoinette Fauve-Chamoux. Together with her colleagues she produced a first volume, House and the Stem Family in Eurasian Perspective in 1998 and six years later a volume on those particular migrant workers who are servants, Domestic Service and the Formation of European Identity. ${ }^{35}$ Thus, although family historians and historical demographers are not working on migration explicitly, there are comparative works, and more in progress, which will add immeasurably to our understanding of the Chinese family and migration through a comparative perspective.

The contribution of Adam McKeown's article under discussion here has been to provide two challenges to Eurocentric histories of migration: McKeown insists that a focus on coolie and forced labor is inappropriate because Chinese had the same reasons for working abroad as did Europeans. Moreover, scholars must attend to the massive migration systems between China, on one hand, and south-east Asia and north Asia, on the other. Each of these challenges can be addressed usefully by investigations of Chinese mobility in terms of demographic patterns and gender relations, both in China and at destinations in south-east and north Asia. This emphasis on family patterns and demography in the global context adds a valuable dynamic to migration in world history because it brings the intimate and vital arena of family processes into view.

34. See The Journal of Asian Studies, 6I (2002), pp. 50 I-663: Philip C.C. Huang, "Development or Involution in Eighteen-Century Britain and China?"; Kenneth Pomeranz, "Beyond the EastWest Binary: Resituating Development Paths in the Eighteenth-Century World"; James Lee, Cameron Campbell, and Wang Feng, "Positive Check or Chinese Checks?"; Robert Brenner and Christopher Isett, "England's Divergence from China's Yangzi Delta: Property Relations, Microeconomics, and Patterns of Development." See also James Lee and Cameron Campbell, "Living Standards in Liaoing, 1749-1909: Evidence from Demographic Outcomes", in Robert Allen et al.(eds), Living Standards in the Past: New Perspectives on Well-Being in Europe and Asia (Oxford 2005), pp. 403-426.

35. Antoinette Fauve-Chamoux and Emiko Ochiai (eds), House and the Stem Family in Eurasian Perspective (Paris, 1998), and Antoinette Fauve-Chamoux (ed.), Domestic Service and the Formation of European Identity: Understanding the Globalization of Domestic Work, I6th2 Ist Centuries (Berne, 2004). 